\title{
People treated for ocular tuberculosis in Colombia
}

\section{Personas atendidas por tuberculosis ocular en Colombia}

\author{
Angie T. Perilla-Rodríguez, Ángela M. Morales-Méndez, Kelly J. Ortega-Figueroa, Paula X. Vela-Peña, \\ Edgar Ibáñez-Pinilla, and Diana García-Lozada* \\ Facultad de Medicina, Universidad El Bosque, Bogotá, Colombia
}

\begin{abstract}
Introduction: Ocular tuberculosis (OTB) can affect any part of the eye, with or without systemic compromise. Despite the large number of investigations related to the burden of tuberculosis (TB) in the world, as a leading cause of morbidity and mortality, few epidemiologic studies on ocular infection have been made. Objective: To determine the frequency of OTB consultations in the general population and in patients with TB, according to the personal health records system (Registro Individual de Prestaciones de Servicios de Salud [RIPS]) between 2013 and 2017 in Colombia. Method: Observational and retrospective study, based on secondary sources of information. Data of patients diagnosed with OTB were obtained from the RIPS, diagnostic code A18.5. The National Statistics Department (Departamento Administrativo Nacional de Estadística) projections and SIVIGILA data, were used as denominators. Results: There were 137 people with OTB between 2013 and 2017. The global rate was 2.8 people attended per million inhabitants; there was an inverse relationship with the year evaluated $(p=0.008)$. In women it was 3.1 and in men 2.5 per million inhabitants $(p=0.275)$. The highest rates were observed in the 75-79 age group (10.2 per million) and in the departments of Putumayo and Santander (5.8 per million inhabitants each). In patients with TB, the frequency of the ocular form was 0.2 per hundred. Conclusions: The frequency in Colombia of people attended for OTB in TB patients was lower than that reported worldwide, perhaps due to underreporting of the number of people attended.
\end{abstract}

Key words: Ocular tuberculosis. Colombia. Factual databases. Epidemiology. Health services.

\section{Resumen}

Introducción: La tuberculosis ocular (TBO) puede afectar cualquier parte del ojo, con o sin compromiso sistémico. A pesar de la gran cantidad de investigaciones relacionadas con la carga de la tuberculosis (TB) en el mundo, como causa principal de morbilidad y mortalidad, son escasos los estudios epidemiológicos sobre la infección ocular. Objetivo: Determinar la frecuencia de atenciones por TBO en población general y en pacientes con TB, según el Registro Individual de Prestación de Servicios de Salud (RIPS) de Colombia, entre 2013 y 2017. Método: Estudio observacional y retrospectivo, basado en fuentes secundarias de información. Se obtuvieron datos de atenciones por TBO según el RIPS, código diagnóstico A18.5. Se utilizaron como denominadores las proyecciones del Departamento Administrativo Nacional de Estadística y datos de TB del SIVIGILA. Resultados: Se identificaron 137 atenciones por TBO entre 2013 y 2017. La tasa global fue de 2.8 personas atendidas por cada millón de habitantes. Hubo relación inversa con el año evaluado ( $p=0.008)$. En las mujeres fue 3.1 $y$ en los hombres 2.5 por millón de habitantes $(p=0.275)$. Las mayores tasas se encontraron en el grupo de 75-79 años

Correspondence:

*Diana García-Lozada

Avda. Cra 9, 131 A-02, Edificio Fundadores, 5.ำ piso

Date of reception: 22-09-2020

Date of acceptance: 16-03-2021

E-mail: dgarcialo@ unbosque.edu.co

DOI: 10.24875/RMOE.M21000173
Available online: 19-03-2021

Rev Mex Oftalmol (Eng). 2021;95(4):142-149

www.rmo.com.mx 2604-1731/@ 2021 Sociedad Mexicana de Oftalmología. Published by Permanyer. This is an open access article under the CC BY-NC-ND license (http://creativecommons.org/licenses/by-nc-nd/4.0/). 
(10.2 por cada millón) y en los departamentos de Putumayo y Santander (5.8 por millón de habitantes cada uno). En pacientes con TB, la frecuencia de TBO fue de 0.2 por cada cien. Conclusiones: La frecuencia en Colombia de atenciones por TBO en pacientes con TB fue inferior a las reportadas en otros países, probablemente por un subregistro del número de personas atendidas.

Palabras clave: Tuberculosis ocular. Colombia. Bases de datos factuales. Epidemiología. Servicios de salud.

\section{Introduction}

The microorganism Mycobacterium tuberculosis is the pathogen that causes tuberculosis (TB), an infectious bacterial disease that is transmitted through the respiratory tract by inhalation of aerosols or fluids from a person who has active TB' ${ }^{1}$. The main organ affected is the lung ${ }^{2}$ and in extrapulmonary locations, the pleura, lymph nodes, genitourinary system, bones, meninges, and skin, among others, can be compromised ${ }^{3}$. The factors that predispose to a greater risk of suffering from this disease are low socioeconomic conditions, immunosuppression, and ethnicity ${ }^{1,2}$. Worldwide, two billion people are infected with $M$. tuberculosis, each year 50 million patients suffer from active TB, and around one million people die as a result of the disease ${ }^{4}$. By 2018, 10 million people fell ill and most of the estimated cases corresponded to the regions of South-East Asia (44\%), Africa (24\%), and the Western Pacific (18\%), and to a lesser extent to the regions of the United States. Eastern Mediterranean $(8 \%)$, Europe $(3 \%)$ and the Americas $(3 \%)^{5}$.

In 2018, in Colombia, 14,446 cases of TB in all forms were notified to the National Public Health Surveillance System (SIVIGILA), with an incidence for the country of 26.9 cases per 100,000 inhabitants; $66 \%$ of the cases were male, $21.3 \%$ were people between the ages of 25 and 34 , and $53 \%$ belonged to the subsidized regime ${ }^{6}$.

According to the American Academy of Ophthalmology, ocular TB (OTB) can affect any part of the eye (intraocular, superficial, or periocular), with or without systemic involvement, since up to $60 \%$ of patients with evidence of extrapulmonary TB may not have been diagnosed with pulmonary TB. Ocular involvement can occur as a primary infection in the conjunctiva, cornea, and sclera, or as a secondary infection from a distant site through the hematogenous spread, affecting the uvea and retina ${ }^{7}$; uveitis may be the first manifestation of a hidden infection ${ }^{8}$.

Epidemiological data on OTB are scarce and unreliable, due to the lack of standardized diagnostic criteria and the difficulty of infection confirmation by laboratory methods ${ }^{9}$. The Collaborative Ocular Tuberculosis Study (COTS) group mentions that the gold standard is the detection of $M$. tuberculosis in tissues or ocular fluids, which is rarely achieved due to the low bacillus load in tissues and the small size of the samples that are obtained from ocular tissue. Therefore, the diagnosis is usually presumptive, based on local epidemiological factors, the ocular phenotype, and the result of immunological tests (tuberculin skin test, interferon-gamma release test [IGRA] or both) and chest $x$-ray ${ }^{10}$.

The search carried out by the authors did not find data on population prevalence of OTB. Regarding the frequency of OTB in TB patients, few studies have been published and with variable results, which have ranged from $18.8 \%$ in Colombia ${ }^{11}$ and $18 \%$ in Spain ${ }^{12}$ to $1.39 \%$ in India ${ }^{13}$. The largest study was that of Donahue ${ }^{14}$ in 1967, in the United States of America, which reported a prevalence of $1.46 \%$ in 10,524 TB patients. The most recent publication is a study in a hospital in the Philippines, ${ }^{15}$ which found a prevalence of $6.8 \%$ (95\% confidence interval: 2.8-13.5).

The Individual Registry for the Provision of Health Services (RIPS) is a database that is part of the Comprehensive Social Protection Information System (SISPRO) of the Ministry of Health of Colombia. It records the services provided in the country each year, whether procedures, outpatient consultation, hospitalization, or emergencies. It is a mandatory information collection tool, regulated by Resolution 3374 of $2000^{16}$, and can be a valuable strategy for monitoring events not included in the SIVIGILA notification sheets, such as OTB. Although there are deficiencies in the quality of the data obtained by the RIPS, more than $83 \%$ of the records are useful for surveillance activities in public health ${ }^{17}$.

The present study sought to determine the frequency of people attended with a diagnosis of OTB in Colombia according to the RIPS, between the years 2013 and 2017 , both in the general population and in patients with TB, taking into account sociodemographic variables such as the department of residence, sex, age, and affiliation to health regimes.

\section{Methods}

An observational and retrospective study was carried out based on secondary sources, by consulting the 
RIPS for the number of people treated with a diagnosis of OTB. The search was carried out on October 26, 2018 with the code A18.5 of the International Classification of Diseases (ICD-10) ${ }^{18}$ in the main diagnosis (the main condition diagnosed at the end of the health care process or consultation, as the primary cause of the patient's request for care), with a date of consultation between 2013 and 2017.

The data of the users attended included in the study were the following: age (in integer values at the time of consultation, grouped in five-year periods), sex (according to the physical condition of the man or woman), department (habitual residence, the place where the person has been living permanently for 6 months or more; in the case of unidentified foreigners, the code of the municipality where the consultation is carried out is filled out) and type of user (according to the type of affiliation to the General System of Social Security in Health: contributory scheme, known as the linking of individuals and their families through an economic contribution financed by the affiliate or in concurrence between him/her and his/her employer, or subsidized scheme, which welcomes those who cannot pay their membership and is maintained thanks to the State subsidy) ${ }^{19}$.

To determine the number of people served in relation to the Colombian population, the national and departmental population projections of the National Administrative Department of Statistics (DANE) were used as denominators. The number of people treated due to OTB in the 5-year period was divided by the average of the estimated population for the five-year period evaluated.

The frequency of consultations for OTB in patients diagnosed with TB was also calculated, using the main TB-related diagnoses in the RIPS as the denominator. The ICD-10 codes related to TB that were included for the RIPS search were the following: A150, A151, A152, A153, A154, A155, A156, A157, A158, A159, A160, A161, A162, A163, A164, A165, A167, A168, A169, A170 A171, A178, A179, A180, A181, A182, A183, A184, A185, A186, A187, A188, A189, A190, A191, A192, A198, A199, JG5X, K230, K673, K930, M011, M490, M900, N333, N740, N741, O980, and P370.

For the calculation of specific consultations by department, sex and type of insurance, we excluded not defined and not reported data, or data recorded as "other".

The information was analyzed with the Microsoft Excel 2018 program. The comparison of proportions of TB and OTB by sex and type of health regimen was made with the binomial test in Epidat 3.1; Spearman's coefficient was used for the correlation between age and OTB. The level of significance used was $5 \%$. The OTB distribution map in the departments of Colombia was prepared with the ArcMap 10.5.1 program, in accordance with the information from the National Geostatistical Framework (MGN) "Geoportal DANE" (https:// geoportal.dane.gov.co/v3).

\section{Results}

\section{OTB in Colombia}

The search for the number of people attended due to OTB resulted in 137 (55.5\% women). The estimated frequency for the 2013-2017 period was 2.8 per million inhabitants, 3.1 in women and 2.5 in men ( $p=0.275)$. The total for each sex may not correspond to the sum since a person who has been attended more than once is only counted one time, or it may include people with unreported sex (Table 1). Regarding the behavior of the cases attended each year, in 2013 it was 0.79 per million inhabitants, while in 2017 it was 0.47 per million (Fig. 1).

Table 2 shows the distribution of the number of consultations by age groups for the years analyzed. The total for each sex may not correspond to the sum since a person who has been attended more than once is only counted one time.

The largest number of people corresponding to the group of 75 to 79 years, with 10.2 per million inhabitants, and the smallest to the group of 5 to 9 years, with 1.2 per million. There was a direct relationship between the age groups and the number of consultations (Spearman: 0.870; $p=0.000$ ).

The departments of Santander and Putumayo had the highest rate of people attended, each with 5.8 per

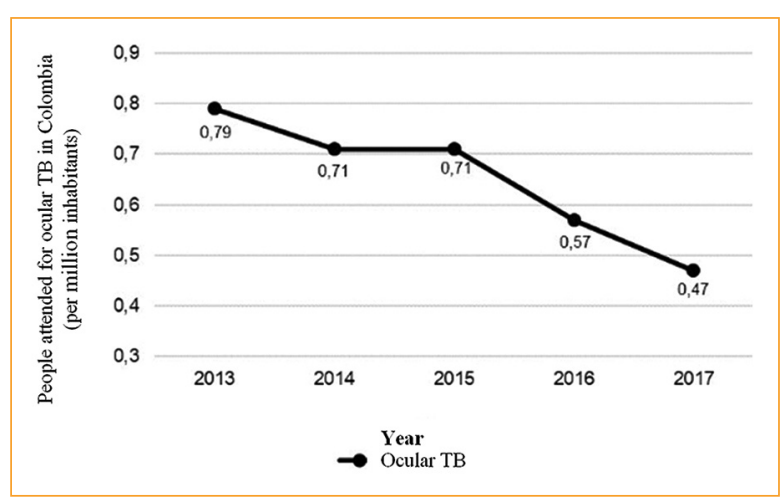

Figure 1. People attended for ocular tuberculosis (OTB) in Colombia (per million inhabitants). 
Table 1. People attended for ocular tuberculosis, by sex

\begin{tabular}{|l|c|c|c|c|c|c|c|c|}
\hline Sex & 2013 & 2014 & 2015 & 2016 & 2017 & Total & $\begin{array}{c}\text { People attended per million } \\
\text { inhabitants }\end{array}$ & $\begin{array}{c}\text { People attended per 100 tuberculosis } \\
\text { patients }\end{array}$ \\
\hline Female & 17 & 22 & 16 & 14 & 16 & 76 & 3.1 & 0.2 \\
\hline Male & 20 & 12 & 18 & 13 & 7 & 60 & 2.5 & 0.2 \\
\hline Total & 37 & 34 & 34 & 28 & 23 & 137 & & \\
\hline
\end{tabular}

Table 2. People attended for ocular tuberculosis by age groups per year

\begin{tabular}{|c|c|c|c|c|c|c|c|c|}
\hline Age (years) & 2013 & 2014 & 2015 & 2016 & 2017 & Total & $\begin{array}{l}\text { People attended per } \\
\text { million inhabitants }\end{array}$ & $\begin{array}{l}\text { People attended per } 100 \\
\text { tuberculosis patients }\end{array}$ \\
\hline 0 to 4 & 0 & 4 & 2 & 2 & 1 & 9 & 2.1 & 0.3 \\
\hline 5 to 9 & 1 & 1 & 2 & 2 & 0 & 5 & 1.2 & 0.3 \\
\hline 10 to 14 & 3 & 3 & 8 & 4 & 3 & 14 & 3.3 & 1.0 \\
\hline 15 to 19 & 1 & 3 & 1 & 1 & 2 & 7 & 1.6 & 0.2 \\
\hline 20 to 24 & 5 & 2 & 1 & 2 & 2 & 9 & 2.1 & 0.2 \\
\hline 25 to 29 & 2 & 3 & 2 & 1 & 0 & 7 & 1.8 & 0.1 \\
\hline 30 to 34 & 3 & 0 & 4 & 3 & 1 & 10 & 2.8 & 0.2 \\
\hline 35 to 39 & 1 & 3 & 1 & 4 & 1 & 9 & 2.8 & 0.2 \\
\hline 40 to 44 & 3 & 0 & 1 & 1 & 3 & 8 & 2.8 & 0.2 \\
\hline 45 to 49 & 5 & 1 & 2 & 1 & 0 & 9 & 3.1 & 0.2 \\
\hline 50 to 54 & 3 & 4 & 0 & 3 & 1 & 11 & 4.1 & 0.2 \\
\hline 55 to 59 & 3 & 3 & 2 & 0 & 3 & 11 & 5.0 & 0.2 \\
\hline 60 to 64 & 3 & 2 & 5 & 2 & 1 & 12 & 7.0 & 0.2 \\
\hline 65 to 69 & 1 & 0 & 0 & 1 & 3 & 5 & 3.8 & 0.1 \\
\hline 70 to 74 & 0 & 2 & 2 & 0 & 1 & 5 & 5.4 & 0.1 \\
\hline 75 to 79 & 4 & 1 & 1 & 1 & 0 & 7 & 10.2 & 0.2 \\
\hline 80 or more & 0 & 2 & 0 & 1 & 1 & 4 & 5.8 & 0.1 \\
\hline Total & 37 & 34 & 34 & 28 & 23 & 137 & & \\
\hline
\end{tabular}

million inhabitants, and it was lower in Cauca and Norte de Santander, with 0.7 per million inhabitants (Table 3). The departments in white in Figure 2 are those that did not report cases of the disease.

Of all people with OTB, $63.5 \%$ were affiliated with the contributory scheme. The figures corresponding to the average number of health affiliates during the five-year period were obtained from SISPRO (accessed on February 5,2018$)$. There were a greater number of diagnoses of OTB in the contributory regime than in the subsidized one ( 4.2 vs. 2.1 per million inhabitants, respectively) $(p=0.000)$.

\section{OTB in TB patients}

The rate of attended people was 0.2 for every 100 TB patients, without differences by sex $(p=0.212)$ (Table 1). According to the type of affiliation, it was 0.3 for every 100 patients for the contributory scheme and 0.1 for every 100 patients for the subsidized scheme $(p=0.000)$. In addition, the results are shown by age (Table 2 ) and department of residence (Table 3).

SIVIGILA provided the information about cases diagnosed with extrapulmonary TB reported in the period; the number of people treated for OTB corresponded to 1.2 
Table 3. People attended for ocular tuberculosis, by residence department

\begin{tabular}{|c|c|c|c|}
\hline Department & $\begin{array}{l}\text { Number } \\
\text { of } \\
\text { attentions }\end{array}$ & $\begin{array}{l}\text { People } \\
\text { attended } \\
\text { per million } \\
\text { inhabitants }\end{array}$ & $\begin{array}{c}\text { People attended } \\
\text { per } 100 \\
\text { tuberculosis } \\
\text { patients }\end{array}$ \\
\hline Santander & 12 & 5.8 & 0.3 \\
\hline Putumayo & 2 & 5.8 & 0.4 \\
\hline Bolivar & 10 & 4.8 & 0.4 \\
\hline Caldas & 4 & 4.1 & 0.3 \\
\hline Magdalena & 5 & 4.0 & 0.4 \\
\hline Antioquia & 24 & 3.7 & 0.1 \\
\hline Bogotá D.C. & 28 & 3.6 & 0.5 \\
\hline Valle del Cauca & 15 & 3.3 & 0.2 \\
\hline Tolima & 4 & 2.8 & 0.2 \\
\hline Boyacá & 3 & 2.4 & 0.4 \\
\hline Córdoba & 4 & 2.3 & 0.2 \\
\hline Risaralda & 2 & 2.1 & 0.1 \\
\hline Caquetá & 1 & 2.1 & 0.1 \\
\hline Cundinamarca & 5 & 1.9 & 0.2 \\
\hline Quindío & 1 & 1.8 & 0.1 \\
\hline Nariño & 3 & 1.7 & 0.1 \\
\hline Atlántico & 4 & 1.6 & 0.1 \\
\hline Sucre & 1 & 1.2 & 0.1 \\
\hline Huila & 1 & 0.9 & 0.1 \\
\hline $\begin{array}{l}\text { Norte de } \\
\text { Santander }\end{array}$ & 1 & 0.7 & 0.1 \\
\hline Cauca & 1 & 0.7 & 0.6 \\
\hline
\end{tabular}

for every 100 extrapulmonary TB diagnoses (including tuberculous meningitis diagnoses in the denominator).

\section{Discussion}

According to the results of this investigation, the rate of people attended for OTB had a decreasing trend during the evaluated years; this was a consequence not only of population increase, but also by the decrease in the number of consultations reported annually. However, no national or international studies were found with population data that allowed for comparisons.

The frequency of OTB in TB patients was lower than other values previously reported. The present study data were taken from the health care registries in Colombia, and the results of other studies were based on figures from reference centers, so the latter could have a selection bias ${ }^{11}$. In addition to having been carried out in different regions and periods, the studies established the diagnosis of OTB according to different clinical criteria, which could be another aspect to consider in the variability of the figures.

It has been mentioned that the cases of people with pulmonary and extrapulmonary TB have decreased over time, and that the decrease in extrapulmonary cases has been slower, so their proportion of the total TB cases has increased ${ }^{3,20}$. However, this study did not find an increase in the proportion of OTB over time. Having found such low frequencies, underestimation of tubercular etiology cannot be excluded ${ }^{9}$. Furthermore, the RIPS do not contain information related to the type of laboratory tests performed to confirm the diagnosis.

Of the reported TB cases in 2017 in Colombia, 40\% corresponded to the departments of Antioquia (18.3\%), Valle del Cauca (13.3\%) and Bogotá (7.8\%) were also the territorial entities in which the highest number of people attended due to OTB was observed between 2013 and 2017. However, eye disease was more frequent in the departments of Santander and Putumayo; It is worth mentioning that this last department only reported 553 TB cases during the period. On the other hand, the departments with the highest number of consultations for OTB in patients with TB were Bogotá and Boyacá. Of the departments with the most people attended, Bolívar is striking, with low rates of TB for the five-year period (2010-2014) ${ }^{22}$ but it had the fifth place for consultations due to OTB and the third place for people attended in the country.

In six departments a single affected person was reported and in 12 departments no cases were reported, eight of which correspond to departments with low frequencies of TB (Guainía, Vaupés, Vichada, Guaviare, Amazonas, Arauca, and Casanare, in addition to the islands of San Andrés and Providencia). In these departments, mainly jungle and remote, we expected a greater number of consultations due to this communicable disease; however, the findings could be explained by the difficulty in accessing health services or by the infrastructure problems that characterize the Amazon-Orinoquía region ${ }^{23}$, specifically in terms of specialists who could detect OTB cases.

Regarding sex, OTB was more frequent in women than in men, both in the Colombian population and in TB patients. Findings in other studies have not shown 


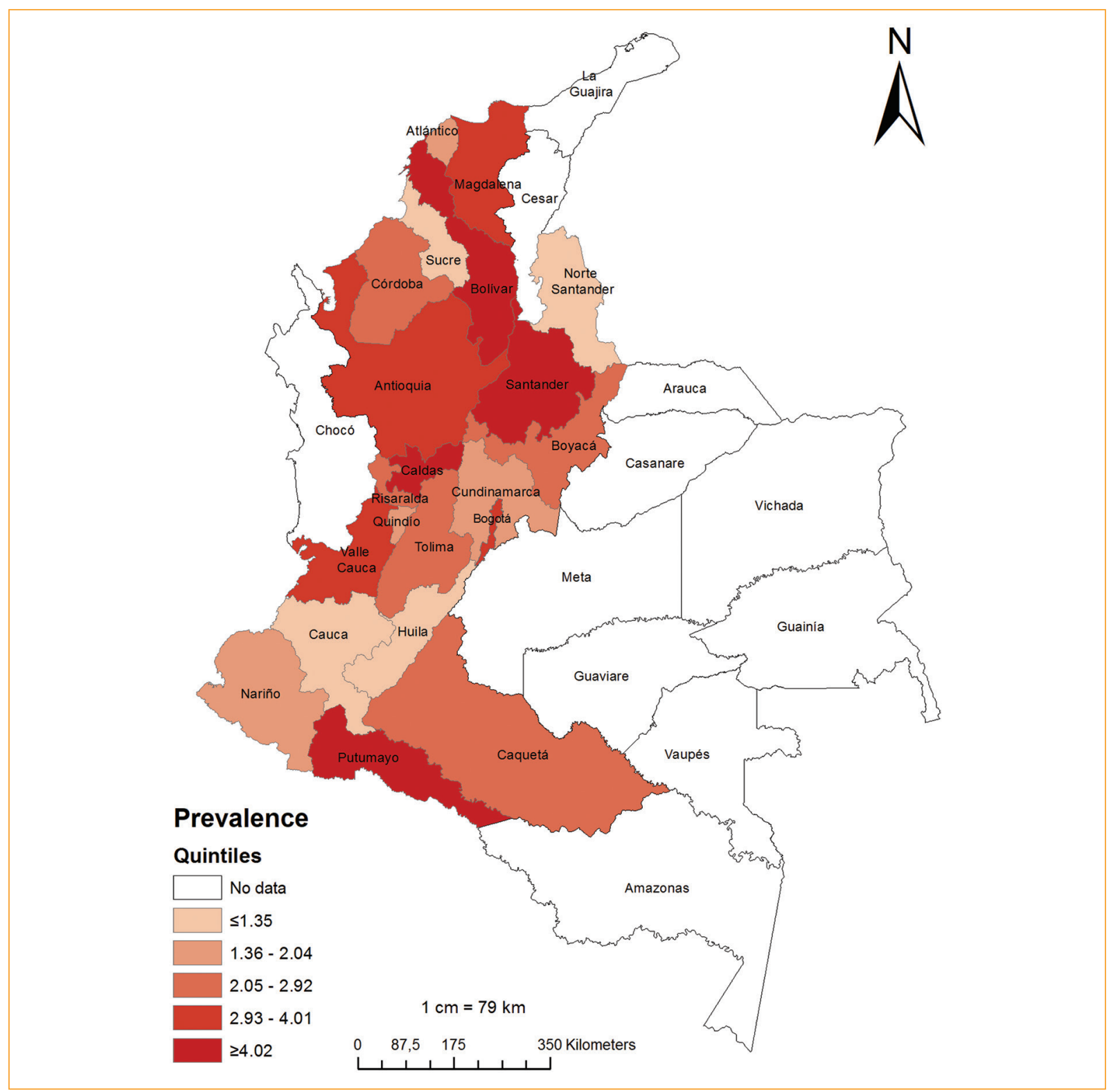

Figure 2. People attended for ocular tuberculosis within the Colombia departments (rates per million).

a relationship between sex and OTB ${ }^{24}$ but it could be assumed a similar trend to that of extrapulmonary TB. Some epidemiological studies with multivariate analysis have found that female sex is a risk factor for developing extrapulmonary $\mathrm{TB}^{3,25}$.

In the Colombian population, the frequency of OTB correlated with age. The age group with more consultations was that of over 50 years of age. It has been mentioned that extrapulmonary TB is more common in elderly patients due to dysregulation of the immune system, malnutrition, and a sedentary lifestyle, which predispose to infection ${ }^{26}$. Grouping in five-year periods, the
10 to 14 age group was the one with the highest number of consultations, much more than in the other groups of children and adolescents. This age group presents a risk for those who are undernourished, under institutional care, or in a homeless situation ${ }^{27}$, but these factors are not registered in the RIPS of OTB. However, among TB patients, the frequency was higher in those under 14 years of age. In this regard, the results of other studies have been contradictory. A Spanish study ${ }^{3}$ reported the association of extrapulmonary TB with age, and a study carried out in Taiwan ${ }^{25}$ showed that age was not associated with the incidence of extrapulmonary TB; on 
the contrary, another study in Nepal ${ }^{28}$ found that there is a greater risk the younger the age.

On the other hand, there was a significant difference according to the type of insurance, with a higher frequency of OTB in the contributory regime, in contrast to what happens with TB cases that affect those affiliated to the subsidized regime to a greater extent. The study did not include socioeconomic or cultural aspects that allowed us to address the possible cause of these differences.

When comparing the data from the two main sources of health information in Colombia, a higher report of people with TB was found in the RIPS $(76,812)$ than in the SIVIGILA $(60,953)$. This can be attributed to the fact that the events reported in SIVIGILA are detected and confirmed through diagnostic procedures by the different operators of the system, as part of the surveillance process. On the contrary, the RIPS data depend on the adequate completion by the professionals who give the consultation, and it is reasonable to assume that it is not done in an optimal way, which can cause a misclassification bias, in addition to the probable underreporting, which may be up to $30 \%$ in morbidity data ${ }^{22}$. This information bias may occur because there is still a fraction of the Colombian population without access to services, or also because some health providers do not report data consistently ${ }^{23}$. In 2013, difficulties were identified in the reporting and quality of data from the capitals of various departments (Cauca, Caldas, Amazonas, Magdalena, Bogotá, Guaviare, Vaupés, Córdoba, Sucre, Vichada, and Guainía) $)^{17}$; therefore, there would be no differential bias attributable to the quality of the data.

One of the limitations of this study is that an underreporting of the consulted data is estimated, perhaps related to the lack of clinical confirmation of the diagnoses, which does not allow us to appreciate the true magnitude of the disease. By relying entirely on secondary sources of information, there may be an information bias due to incorrect completion. In addition, the RIPS information on OTB does not contain the ocular findings that were detected in the people attended, the affected eye or the tests used to confirm the diagnosis. In fact, the diagnosis of OTB continues to be a challenge for ophthalmologists and pneumologists because a reference method has not been defined, ${ }^{29}$ so diagnosis is mainly based on clinical findings. For this reason, several experts have proposed the adoption and dissemination of a unified terminology that allows a better understanding of the disease ${ }^{30}$, not only in its clinical aspects, but also in its epidemiological aspects.

\section{Conclusions}

This study presents the consultations for OTB in Colombia as rates in the general population and in patients with TB, the latter being considerably lower than others previously reported, reflecting a probable underreporting. There are very few epidemiological data on the distribution of OTB to allow comparisons with our results. Awareness should be created among health professionals about the possibility of ocular disease in patients with TB, so that they can search for ocular signs even in asymptomatic patients and, additionally, so that they can reliably report on the RIPS. Although it is not one of the most frequent extrapulmonary forms, OTB may be a primary manifestation that allows a systemic diagnosis.

\section{Acknowledgments}

To Laura Cabezas Pinzón, environmental engineer and researcher at the Instituto de Salud y Ambiente de la Vicerrectoría de Investigaciones de la Universidad El Bosque for her help with the preparation of the distribution map in the departments of Colombia.

\section{Funding}

No funding was received for the development of this research.

\section{Conflicts of interest}

The authors declare no conflict of interest.

\section{Ethical disclosures}

Protection of human and animal subjects. The authors declare that no experiments were performed on humans or animals for this study.

Confidentiality of data. The authors declare that no patient data appear in this article.

Right to privacy and informed consent. The authors declare that no patient data appear in this article.

\section{References}

1. Thomas TA. Tuberculosis in children. Thorac Surg Clin. 2019;29:109-21.

2. Shakarchi FI. Ocular tuberculosis: current perspectives. Clin Ophthalmol. 2015;9:2223-7.

3. García-Rodríguez J, Álvarez-Díaz $H$ Lorenzo-García M Mariño-Callejo A, Fernández-Rial A, Sesma-Sánchez P. Extrapulmonary tuberculosis: epidemiology and risk factors. Enferm Infecc Microbiol Clin. 2011;29:502-9. 
4. GBD Tuberculosis Collaborators. The global burden of tuberculosis: results from the Global Burden of Disease Study 2015. Lancet Infect Dis 2018;18:261-84.

5. Organización Mundial de la Salud. Informe mundial sobre la tuberculosis 2019 - Sinopsis. 2019. (Consultado el 18 de octubre de 2019.) Disponible en: https://www.who.int/tb/publications/global_report/gtbr2019_ExecutiveSummary sp.pdf?ua $=1$

6. Instituto Nacional de Salud. Colombia. López M. Informe del evento. Tuberculosis, Colombia 2018. 2019. (Consultado el 30 de septiembre de 2019.) Disponible en: https://www.ins.gov.co/buscador-eventos/Informesdeevento/TUBERCULOSIS 2018.pdf

7. American Academy of Ophhalmology. San Francisco: The Academy 2014. Ocular tuberculosis (TB) - Asia Pacific. 2019. (Consultado el 29 de marzo de 2019.) Disponible en: https://www.aao.org/topic-detail/ocular-tuberculosis-tb--asia-pacific-2.

8. Agrawal R, Gunasekeran DV, Raje D, Agarwal A, Nguyen QD, Kon OM, et al. Global variations and challenges with tubercular uveitis in the CoIlaborative Ocular Tuberculosis Study. Invest Ophthalmol Vis Sci. 2018;59:4162-71.

9. Khairallah M, Jelliti B, Attia S. Uveitis in the developing world. Expert Rev Ophthalmol. 2010;5:161-76.

10. Agrawal R, Testi I, Mahajan S, Yuen YS, Agarwal A, Kon OM, et al. Collaborative Ocular Tuberculosis Study consensus guidelines on the management of tubercular uveitis - report 1: guidelines for initiating antitubercular therapy in tubercular choroiditis. Ophthalmology. 2021:128:266-76.

11. Fonseca EVF, Yunda LFI, Herrera KCM, Moreno GC. Extrapulmonary tuberculosis in Colombian children: epidemiological and clinical data in a reference hospital. Int J Mycobacteriol. 2017;6:132-7.

12. Bouza E, Merino $P$, Muñoz $P$, Sánchez-Carrillo $C$, Yáñez J, Cortes $C$. Ocular tuberculosis. A prospective study in a general hospital. Medicine (Baltimore). 1997;76:53-61.

13. Biswas J, Badrinath SS. Ocular morbidity in patients with active systemic tuberculosis. Int Ophthalmol. 1995;19:293-8.

14. Donahue HC. Ophthalmologic experience in a tuberculosis sanatorium. Am J Ophthalmol. 1967:64:742-8.

15. Lara LP, Ocampo V. Prevalence of presumed ocular tuberculosis among pulmonary tuberculosis patients in a tertiary hospital in the Philippines. Ophthalmic Inflamm Infect. 2013;3:1.

16. Colombia. Ministerio de Salud Pública. Resolución 3374 de 2000 (diciembre 27): Por la cual se reglamentan los datos básicos que deben reportar los prestadores de servicios de salud y las entidades administradoras de planes de beneficios sobre los servicios de salud prestados. Bogotá D.C.; 27 de diciembre de 2000. (Consultado el 26 de octubre de 2019.) Disponible en: https://www.nuevaeps.com.co/sites/default/files/inline-files/resolucion3374-de-2000.pdf
17. Martínez M, Pacheco O. Utilidad de los Registros Individuales de Prestación de Servicios (RIPS) para la vigilancia en salud pública, Colombia, 2012. Instituto Nacional de Salud; 2013. p. 176-92.

18. Organización Panamericana de la Salud. Clasificación estadística internacional de enfermedades y problemas relacionados con la salud. 10. revisión. Washington, D.C.: OPS; 2018.

19. Colombia. Ministerio de Salud y Protección Social. Oficina de Tecnología de Información y Comunicaciones. Lineamiento técnico para el registro y envío de los datos del Registro Individual de Prestaciones de Salud RIPS, desde las instituciones prestadoras de servicios de salud a las EAPB. Versión 8. 2019. (Consultado el 14 de enero de 2021.) Disponible en: https://www.minsalud.gov.co/sites/rid/Lists/BibliotecaDigital/RIDE/DE/ OT/Lineamientos-Tecnicos-para-IPS.pdf

20. Peto HM, Pratt RH, Harrington TA, LoBue PA, Armstrong LR. Epidemiology of extrapulmonary tuberculosis in the United States, 1993-2006. Clin Infect Dis. 2009;49:1350-7.

21. Instituto Nacional de Salud. Colombia. López M. Informe del evento. Tuberculosis, Colombia 2017. 2018. (Consultado el 30 de septiembre de 2019.) Disponible en: https://www.ins.gov.co/buscador-eventos/Informesdeevento/Tuberculosis\%202017.pdf

22. Pedraza A. Estimación de la carga de enfermedad por tuberculosis en Colombia, 2010 a 2014. [Tesis de maestría]. Bogotá: Facultad de Medicina, Universidad El Bosque; 2017.

23. Bernal O, Forero JC, Villamil MP, Pino R. Disponibilidad de datos y perfil de morbilidad en Colombia. Rev Panam Salud Pública. 2012:31:181-7.

24. Win M, Chee SP. Epidemiological aspects of ocular tuberculosis. En: Kumar A, Chawla R, Sharma N, editores. Ocular tuberculosis. Suiza: Springer International Publishing; 2017. p. 1-6.

25. Lin JN, Lai CH, Chen YH, Lee SS, Tsai SS, Huang CK, et al. Risk factors for extra-pulmonary tuberculosis compared to pulmonary tuberculosis. Int J Tuberc Lung Dis. 2009;13:620-5.

26. García-Goez J, Munévar H, Pacheco R. Tuberculosis en pacientes mayores de 80 años atendidos en una institución de alta complejidad. Rev Colomb Neumol. 2017;29:19-25.

27. Tovar M, Tang A, Concha N. Tuberculosis extrapulmonar en pediatría: un reto diagnóstico. Medicas UIS. 2013;2b:45-58.

28. Sreeramareddy CT, Panduru KV, Verma SC, Joshi HS, Bates MN. Comparison of pulmonary and extrapulmonary tuberculosis in Nepal - a hospital-based retrospective study. BMC Infect Dis. 2008;8:8

29. Lee C, Agrawal R, Pavesio C. Ocular tuberculosis - a clinical conundrum. Ocul Immunol Inflamm. 2016;24:237-42.

30. Agrawal R, Agarwal A, Jabs DA, Kee A, Testi I, Mahajan S. Standardization of nomenclature for ocular tuberculosis - results of Collaborative Ocular Tuberculosis Study (COTS) Workshop. Ocul Immunol Inflamm. 2019 Dec 10;1-11. doi: 10.1080/09273948.2019.1653933. Online ahead of print. 